\title{
Multicriteria analysis in selecting the optimal variant of solar system
}

\author{
Aleksandra Radziejowska ${ }^{1, a}$ and Krzysztof Zima² \\ ${ }^{1}$ Department of Geomechanics, Civil Engineering and Geotechnics, Faculty of Mining and Geoengineering, AGH University Of \\ Science And Technology in Cracow, Poland \\ ${ }^{2}$ Institute of Construction and Transportation Engineering \& Management, Faculty of Civil Engineering, Cracow University Of \\ Technology, Poland
}

\begin{abstract}
Alternative energy sources are becoming more serious competition to traditional ways of generating energy. It becomes real integration of eco-energy with ecology, as well as the innovative technologies with low-energy construction. Apart from the cost an important issue are technical parameters of the equipment, durability, ease of installation, etc. The investor therefore is facing with the problem of decision-making to choose the best solution from the point of view of many criteria. In the article, the authors present the proposal to apply the methods of multi-criteria analysis to select the most beneficial variant of the solar system solutions. In this purpose will be use among other method: multivariate analysis of Saaty's AHP, the taxonomic method of weighting factors and, belonging to a group of methods using outranking relations, the Promethee II method. Proposed comparative analysis can be used as a method for decision support during the selection of the most beneficial technological solution of solar installation and to evaluate operational efficiency existing buildings which will have implemented new systems.
\end{abstract}

\section{Introduction}

Nowadays, both in residential and commercial buildings are increasingly being used solutions for the application of environmentally friendly energy sources. Application of solar installations as one of the energy sources brings measurable effects of fulfilling the basic principles of sustainable development among which should be mentioned the environmental, economic and social aspects.

Heating water with solar energy is one of the most effective ways of energy conversion of solar radiation. That is why, the most frequently offered solar collectors are used to heat hot water. Such usage of solar installations is the most widely used in countries with high insolation, where the use of solar energy provides measurable benefits for most of the year. However, over time these installations began to arouse greater interest also in countries with temperate climates. However, countries with less favorable climatic conditions were required some modifications hitherto applied solutions, which resulted, among other, of the following occurring the negative temperatures in these regions [1]. Improvements in solar installations were required cold hardiness materials and additional support conventional heat sources.

Currently on the manufacturers of solar collectors market appears a variety of solutions, which are used to convert solar energy into heat. Solar energy that gets directly to the device is converted by the heat transfer

\footnotetext{
${ }^{a}$ Corresponding author: aradziej@agh.edu.pl
}

medium, which may be a liquid (eg. glycol, water) or gas (eg. air) into heat energy. The analysis can cover flat solar systems, some of which are a gas-filled, liquid-filled or two-phase and flat-vacuum solution, vacuum-tube or concentrating systems.

More often, due to the additional initial costs and long payback period for the building object, selection of the most beneficial source of renewable energy is becoming problem of the private and the public investor. Apart from the cost an important issue are technical parameters of the equipment, durability, ease of installation, etc. The investor therefore is facing with the problem of decision-making to choose the best solution from the point of view of many criteria. In view of the above, authors present the proposal to apply the methods of multi-criteria analysis to select the most beneficial variant of the solar system solutions.

\section{Short literature review}

The problem of choosing the best solution from the point of view of many criteria is frequently described in the literature. The article focuses on the multi-criteria analysis of the best solution involving the installation of solar collector systems. Huang et al. [2] tried to select an optimum solar ejector cooling system. Authors selected three commercially available solar collectors for comparison and discussed best solution. It seems that in order to select the best solutions it should be supported by mathematical methods. 
Aragonés-Beltrán et al. [3] used an AHP (Analytic Hierarchy Process) and the ANP (Analytic Network Process) methods to help the managing board of an Spanish solar power investment company. The system help to decide whether to accept or reject a project according to a set and establishing a priority order among the projects.

J.R. San Cristóbal in [4] shows a Compromise Ranking method (known as VIKOR method), using multi-criteria ranking index based on the measure of "closeness" to the "ideal" solution for renewable energy project in Spain.

The importance of the problem related with choosing panel systems has been addressed, among others, in [5]. Choosing an optimal solution of a solar collector installation for a single-family building is done using the CBR method based on a database containing the costs of 128 projects involving the installation of solar collectors. The example uses 10 evaluation criteria adopted solutions.

The problem of designing related to technical characteristics has been described among others in [6], [7]. In this article authors analyze the differences between the value of the contract and the offers submitted in 2013 in public procurement for a solar collectors.

\section{Decision-making methods}

For many years, researchers are developing methods of support, which are designed to facilitate resolving the situation ambiguous in various fields of human activity. About the decision-making process in the tender wrote among others in [8], [9]. The search for methods of solving multicriteria problems first appeared in the late nineteenth and early twentieth century. Since then, there was create a number of studies and methods of searching for the optimal solution (Table 1).

Table 1. Application areas of multi-criteria methods [4]

\begin{tabular}{|c|c|}
\hline Method & Application area \\
\hline $\begin{array}{c}\text { Multi - objective decision } \\
\text { making }\end{array}$ & $\begin{array}{l}\text { RE planning and RE economic } \\
\text { planning }\end{array}$ \\
\hline Decision support systems & RE planning \\
\hline $\begin{array}{l}\text { Analytical Hierarchy } \\
\text { Process }\end{array}$ & $\begin{array}{l}\text { RE planning and wind farm } \\
\text { projects }\end{array}$ \\
\hline PROMETHEE & $\begin{array}{l}\text { Geothermal projects, hydro-site- } \\
\text { selection }\end{array}$ \\
\hline ELECTRE & RE planning \\
\hline $\begin{array}{l}\text { Multi - attribute utility } \\
\text { theory }\end{array}$ & $\begin{array}{l}\text { Solar energy projects and RE } \\
\text { planning }\end{array}$ \\
\hline Fuzzy programming & $\begin{array}{l}\text { Wind site selection and Solar } \\
\text { System }\end{array}$ \\
\hline
\end{tabular}

The aim of the multi-criteria analysis is the choice of the optimal variant taking into account different criteria to be a major impact on the implementation and functioning of the solution. Multi-criteria analysis mainly focuses on discrete problems, which include issues of countable number of criteria and / or decisions. Today there are many proposals for analysis and synthesis of discrete multicriteria problems, which allow to solve difficult and complex issues [10].
The authors of this paper present the application of three selected methods, each of them belongs to a different group, which differ, among others, approach and way of finding the optimal solution.

The first of these, and also the oldest is classified as taxonomic methods, it consists on the construction of scalar, whose numerical value is a synthetic evaluation index 5 [11]. Aggregation of assessment can be carried out after coding the criteria values, usually expressed in various, not comparable with each other units. Both the choice of the synthetic index and coding method can slightly affect on result of the assessment. Therefore, the authors propose to use two methods of coding, in order to verify the results (Table 2).

Table 2. Coding method and synthetic evaluation index used in analysis.

\begin{tabular}{|c|c|c|c|}
\hline Coding & Stimulant & Destimulant & $\begin{array}{l}\text { Synthetic } \\
\text { Evaluation } \\
\text { Index }\end{array}$ \\
\hline $\begin{array}{l}\text { Neuman - } \\
\text { Morgenstern }\end{array}$ & $z_{i j}=\frac{x_{i j}-x_{j \min }}{x_{j \max }-x_{j \mathrm{~m}}}$ & $z_{i j}=\frac{x_{j \max }-x_{i j}}{x_{j \max }-x_{j \min }}$ & \multirow{2}{*}{$\begin{array}{c}\text { Adjusted } \\
\text { index of } \\
\text { summation } \\
J_{i}=\sum_{j=1}^{m}\left(z_{i j} \cdot v_{j}\right)\end{array}$} \\
\hline normalization & $z_{i j}=\frac{x_{i j}}{x_{j \max }}$ & $z_{i j}=\frac{x_{i j}^{\prime}}{x_{j \max }^{\prime}} ; \quad x_{i j}^{\prime}=\frac{1}{x_{i j}}$ & \\
\hline \multicolumn{4}{|c|}{$\begin{array}{l}x_{i j}-\text { maximum value of } \mathrm{j} \text {-th criterion after maximization } \\
x_{j \max } \text { - maximum value of } \mathrm{j} \text {-th partial criterion } \\
\boldsymbol{x}_{j \min } \text { - minimum value of } \mathrm{j} \text {-th partial criterion } \\
v_{j} \text {-weight of } \mathrm{j} \text {-th criterion }\end{array}$} \\
\hline
\end{tabular}

Second method, that authors propose to apply is Analytic Hierarchy Process (AHP) method, which has been developed by Thomas L. Saaty [12] Users of the AHP method first decompose their decision problem into a hierarchy of more easily comprehended sub-problems and then the decision makers systematically evaluate various elements by comparing them to each other two at a time, with respect to their impact on an element above them in the hierarchy. More than forty years AHP method is the reason for many disputes among scientific elite, because a large subjectivity of the process of finding the optimal solution. However, over the last years, AHP method becomes very popular, and despite the controversy it induces, so far, no one has managed to undermine the correctness of its operation.

The final method that was used to analyzed the problem of multi-criteria is PROMETHEE II (Preference Ranking Organization Method for Enrichment Evaluations)) belonging to the group of method based on identifying relationships outranking. PROMETHEE method uses information about the extent to which (on average) the alternative is preferable over the others (positive flow of preferences), and the extent to which the rest of the alternatives is preferable than given (negative flow of preferences). 


\section{The set of analyzed variants and criteria}

Taking into account a number of assessment criteria analysis using the mathematical methods may include various solar collectors: flat-plate, some of which are gas, liquid-based or two-phase collectors and vacuum, vacuum-tube or focusing solar collectors. In order to assess the suitability of different multi-criteria methods to choose the best solution was analyzed three selected collectors: flat-plate collector Logasol SKN 4.0, vacuum collector Depsol DS 20 and vacuum collector HEVELIUS SCM-20 58/1800.

The collector Logasol SKN 4.0 is an universal flat-plate collector designed primarily for the needs of a few people family with the possibility of installation on a sloping roof, flat, facade and in the roof. Solar collectors Logasol SKN 4.0 are $2,25 \mathrm{~m}^{2}$ net aperture area, and are the ideal solution dedicated to heat utility water and central heating support. The collector includes aluminum absorber covered by a highly selective coating of black chrome applied by the vacuum method, which increases the durability of the collector.

Vacuum collector Depsol DS 20 designed for solar installation with 150-200 liter utility water heater for 2-4 people. Depsol DS 20 is a vacuum collector mounted on sloped roof, flat roof or directly on a vertical wall of the building. Vacuum collector Depsol DS 20 is a combination of the best features of vacuum collectors and flat plate collectors.

The solar collector Depsol DS is similar to the flat panel divided into a plurality of tubular elements. Each vacuum tube is a separate heating unit which is a flat absorber direct flow locked in vacuum. Depsol DS collectors are used to heat the hot utility water and support the central heating. In contrast to the collector Logasol SKN 4.0, Depsol has a copper absorber, coated with a layer with Tinox titanium oxide.

HEVELIUS SCM-20 collector is primarily intended for applications in large investment properties (due to the relatively large absorber area), but also works in Solar sets for several persons households. The collector is designed for use on horizontal surfaces and pitched roofs. It is built from double-walled vacuum glass tubes, made of tempered glass borosilicate.

It has a surface absorption gradually selective Al-N / Al. The distinctive feature of the HEVELIUS SCM-20 collectors is to use the Heat-Pipe technology. It consists in heating the lower end of the tube which is placed within the collector. This causes a phenomenon of evaporation of the liquid by taking heat as steam moves to the upper part of the tube. There subsequently condenses on the cold walls, releasing heat. The efficiency of heat transfer by convection combined with the evaporation is much more efficient than the thermal conduction through the solid matter.

The set of criteria that have been included in conducted multi-criteria analysis and values for the selected variants are presented in Table 3.
Table 3. A set of criteria considered in the multi-criteria evaluation.

\begin{tabular}{|c|c|c|c|c|}
\hline Lp & $\begin{array}{l}\text { Variant/ } \\
\text { Method }\end{array}$ & $\begin{array}{c}\text { A - Logasol } \\
\text { SKN 4.0* }\end{array}$ & $\begin{array}{c}\text { B - Depsol } \\
\text { DS 20* }\end{array}$ & $\begin{array}{c}\text { C - } \\
\text { HEVELIU } \\
\text { S SCM-20 } \\
58 / 1800^{*}\end{array}$ \\
\hline $\mathrm{c} 1$ & $\begin{array}{c}\text { Net } \\
\text { Aperture } \\
\text { Area }\end{array}$ & $2,25 \mathrm{~m}^{2}$ & $2, \mathrm{~m}^{2}$ & $2,6 \mathrm{~m}^{2}$ \\
\hline $\mathrm{c} 2$ & $\begin{array}{c}\text { Fluid } \\
\text { Content }\end{array}$ & 1,351 & 2,641 & 1,51 \\
\hline $\mathrm{c} 3$ & Dry Weight & $41 \mathrm{~kg}$ & $45 \mathrm{~kg}$ & $49 \mathrm{~kg}$ \\
\hline $\mathrm{c} 4$ & Net price & $2199,00 \mathrm{zł}$ & $2999,00 \mathrm{zl}$ & $2977,00 \mathrm{zl}$ \\
\hline $\mathrm{c} 5$ & $\begin{array}{c}\text { Optical } \\
\text { efficiency }\end{array}$ & $77 \%$ & $78 \%$ & $69,7 \%$ \\
\hline c6 & $\begin{array}{c}\text { Absorber } \\
\text { Material }\end{array}$ & aluminum & copper & Al.-N/Al. \\
\hline c7 & A1 index & $\begin{array}{c}3,87 \mathrm{~W} /\left(\mathrm{m}^{2}\right. \\
\mathrm{K})\end{array}$ & $\begin{array}{c}1,936 \\
W /\left(m^{2} \mathrm{~K}\right)\end{array}$ & $\begin{array}{c}1,696 \\
W /\left(m^{2} \mathrm{~K}\right)\end{array}$ \\
\hline $\mathrm{c} 8$ & A2 index & $\begin{array}{c}0,012 \\
\mathrm{~W} /\left(\mathrm{m}^{2} \mathrm{~K}^{2}\right)\end{array}$ & $\begin{array}{c}0,006 \\
\mathrm{~W} /\left(\mathrm{m}^{2} \mathrm{~K}^{2}\right) \\
\end{array}$ & $\begin{array}{c}0,0099 \\
\mathrm{~W} /\left(\mathrm{m}^{2} \mathrm{~K}^{2}\right) \\
\end{array}$ \\
\hline c9 & Warranty & 5 years & 10 years & 5 years \\
\hline $\mathrm{c} 10$ & $\begin{array}{l}\text { Maximum } \\
\text { stagnation } \\
\text { temperature }\end{array}$ & $199^{\circ} \mathrm{C}$ & $191,9^{\circ} \mathrm{C}$ & $225,4{ }^{0} \mathrm{C}$ \\
\hline $\mathrm{c} 11$ & $\begin{array}{l}\text { Versatility } \\
\text { (grading 1- } \\
5 \text { ) }\end{array}$ & 3 & 3 & 4 \\
\hline
\end{tabular}

* data from the manufacturer and dealers.

\section{Results and Discussion}

A comprehensive review of MCDM (Multi-Criteria Decision Making) methods was undertaken to compare variants. The analyzed methods include weighted sum/product method, analytical hierarchy process (AHP) and preference ranking organization method for enrichment evaluation (PROMETHEE). Below, the authors present partial calculations for each of them. First step in taxonomic methods is coding values which is shown in Table 4.

Table 4. Values coded by using the method of normalization / Neumann - Morgenstern

\begin{tabular}{|c|c|c|c|c|c|c|}
\hline \multirow{2}{*}{ Criteria } & \multicolumn{2}{|c|}{$\begin{array}{c}\text { Logasol } \\
\text { SKN 4.0 }\end{array}$} & \multicolumn{2}{c|}{$\begin{array}{c}\text { Depsol } \\
\text { DS 20 }\end{array}$} & \multicolumn{2}{c|}{$\begin{array}{c}\text { HEVELIUS } \\
\text { SCM-20 } \\
\mathbf{5 8 / 1 8 0 0}\end{array}$} \\
\hline $\mathbf{c 1}$ & $0,87 /$ & 0,42 & $0,77 /$ & 0,00 & $1,00 /$ & 1,00 \\
\hline $\mathbf{c 2}$ & $0,51 /$ & 0,00 & $1,00 /$ & 1,00 & $0,57 /$ & 0,12 \\
\hline $\mathbf{c 3}$ & $1,20 /$ & 1,00 & $1,09 /$ & 0,50 & $1,00 /$ & 0,00 \\
\hline $\mathbf{c 4}$ & $1,36 /$ & 1,00 & $1,00 /$ & 1,00 & $1,01 /$ & 0,03 \\
\hline $\mathbf{c 5}$ & $0,99 /$ & 0,88 & $1,00 /$ & 1,00 & $0,89 /$ & 0,00 \\
\hline $\mathbf{c 6}$ & $0,67 /$ & 0,50 & $0,33 /$ & 0,00 & $1,00 /$ & 1,00 \\
\hline $\mathbf{c 7}$ & $1,00 /$ & 0,00 & $2,00 /$ & 0,11 & $2,28 /$ & 1,00 \\
\hline $\mathbf{c 8}$ & $1,00 /$ & 0,00 & $2,00 /$ & 0,00 & $1,21 /$ & 0,35 \\
\hline $\mathbf{c 9}$ & $0,50 /$ & 0,00 & $1,00 /$ & 1,00 & $0,50 /$ & 0,00 \\
\hline $\mathbf{c 1 0}$ & $0,88 /$ & 0,21 & $0,85 /$ & 0,00 & $1,00 /$ & 1,00 \\
\hline $\mathbf{c 1 1}$ & $0,75 /$ & 0,00 & $0,75 /$ & 0,00 & $1,00 /$ & 1,00 \\
\hline
\end{tabular}


Coded values were multiplied by the weight vector, then calculated according to the formula showed in Table 2 for adjusted index of summation (Table 5). Weights were based on expert judgment.

Table 5. The adjusted index of summation (IS) for two coding methods

\begin{tabular}{|c|c|c|c|c|c|c|}
\hline \multirow{2}{*}{} & \multicolumn{3}{|c|}{ Normalization } & \multicolumn{3}{c|}{$\begin{array}{c}\text { Neumanna- } \\
\text { Morgensterna }\end{array}$} \\
\cline { 2 - 7 } & $\mathrm{A}$ & $\mathrm{B}$ & $\mathrm{C}$ & $\mathrm{A}$ & $\mathrm{B}$ & $\mathrm{C}$ \\
\hline $\mathrm{c} 1$ & 0,05 & 0,05 & 0,06 & 0,02 & 0 & 0,06 \\
\hline $\mathrm{c} 2$ & 0,04 & 0,08 & 0,04 & 0 & 0,08 & 0,01 \\
\hline $\mathrm{c} 3$ & 0,04 & 0,03 & 0,03 & 0,03 & 0,02 & 0 \\
\hline $\mathrm{c} 4$ & 0,23 & 0,17 & 0,17 & 0,17 & 0,17 & 0,01 \\
\hline $\mathrm{c} 5$ & 0,13 & 0,13 & 0,12 & 0,11 & 0,13 & 0 \\
\hline $\mathrm{c} 6$ & 0,05 & 0,03 & 0,08 & 0,04 & 0 & 0,08 \\
\hline $\mathrm{c} 7$ & 0,11 & 0,23 & 0,26 & 0 & 0,01 & 0,11 \\
\hline $\mathrm{c} 8$ & 0,11 & 0,23 & 0,14 & 0 & 0 & 0,04 \\
\hline $\mathrm{c} 9$ & 0,04 & 0,08 & 0,04 & 0 & 0,08 & 0 \\
\hline $\mathrm{c} 10$ & 0,07 & 0,07 & 0,08 & 0,02 & 0 & 0,08 \\
\hline $\mathrm{c} 11$ & 0,05 & 0,05 & 0,07 & 0 & 0 & 0,07 \\
\hline IS & $\mathbf{0 , 9 2 6}$ & $\mathbf{1 , 1 3 6}$ & $\mathbf{1 , 0 8 3}$ & $\mathbf{0 , 3 9 1}$ & $\mathbf{0 , 4 8 2}$ & $\mathbf{0 , 4 5 5}$ \\
\hline
\end{tabular}

Second method used in proposal analysis was AHP. Decomposition of discussed problem into a hierarchy is shown in Figure 1.

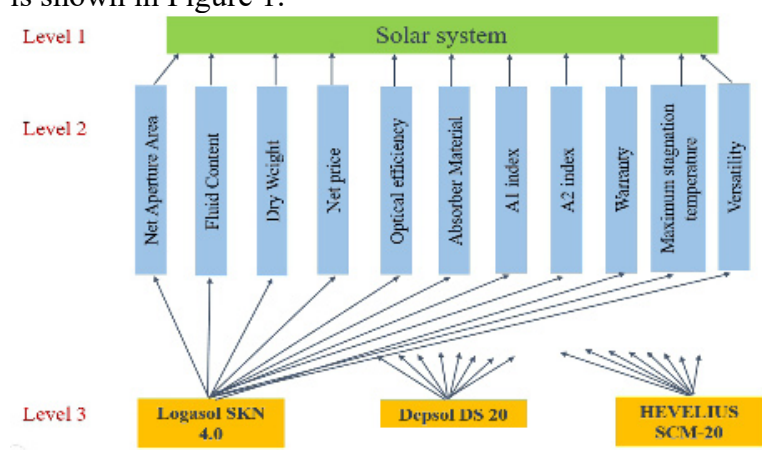

Figure 1. Decomposition for solar system (Source: own).

Calculations for the second level is shown in Table 6 .

Table 6. Calculation of eigenvectors for second level in AHP method

\begin{tabular}{|c|c|c|}
\hline No & Criterion & Vector wi \\
\hline c1 & Net Aperture Area & 0,032 \\
\hline c2 & Fluid Content & 0,042 \\
\hline c3 & Dry Weight & 0,016 \\
\hline $\mathrm{c} 4$ & Net price & 0,264 \\
\hline $\mathrm{c} 5$ & Optical efficiency & 0,157 \\
\hline c6 & Absorber Material & 0,049 \\
\hline c7 & A1 index & 0,141 \\
\hline $\mathrm{c} 8$ & A2 index & 0,144 \\
\hline c9 & Warranty & 0,058 \\
\hline $\mathrm{c} 10$ & Maximum stagnation temperature & 0,062 \\
\hline \multirow[t]{4}{*}{$\mathrm{c} 11$} & Versatility & 0,035 \\
\hline & $\lambda \max$ & 12,12 \\
\hline & C.I. & 0,11 \\
\hline & C.R. & $\mathbf{0 , 0 7}$ \\
\hline
\end{tabular}

And the third level (Table 7).

Table 7. Calculation of eigenvectors for second level in AHP method

\begin{tabular}{|c|c|c|c|c|c|c|}
\hline Lp & $\begin{array}{c}\text { Logasol } \\
\text { SKN } \\
\mathbf{4 . 0}\end{array}$ & $\begin{array}{c}\text { Depso } \\
\text { I } \\
\text { DS 20 }\end{array}$ & $\begin{array}{c}\text { HEVEL } \\
\text { IUS } \\
\text { SCM-20 } \\
\mathbf{5 8} / \mathbf{1 8 0 0}\end{array}$ & $\boldsymbol{\lambda}_{\max }$ & C.I. & C.R. \\
\hline c1 & 0,27 & 0,12 & 0,61 & $\mathbf{3 , 1 0}$ & $\mathbf{0 , 0 5}$ & $\mathbf{0 , 0 9}$ \\
\hline c2 & 0,18 & 0,68 & 0,20 & $\mathbf{3 , 0 4}$ & $\mathbf{0 , 0 2}$ & $\mathbf{0 , 0 3}$ \\
\hline c3 & 0,54 & 0,30 & 0,16 & $\mathbf{3 , 0 1}$ & $\mathbf{0 , 0 1}$ & $\mathbf{0 , 0 1}$ \\
\hline c4 & 0,63 & 0,17 & 0,19 & $\mathbf{3 , 0 1}$ & $\mathbf{0 , 0 1}$ & $\mathbf{0 , 0 1}$ \\
\hline c5 & 0,43 & 0,43 & 0,14 & $\mathbf{3 , 0 0}$ & $\mathbf{0 , 0 0}$ & $\mathbf{0 , 0 0}$ \\
\hline c6 & 0,30 & 0,16 & 0,54 & $\mathbf{3 , 0 1}$ & $\mathbf{0 , 0 1}$ & $\mathbf{0 , 0 1}$ \\
\hline c7 & 0,07 & 0,35 & 0,58 & $\mathbf{3 , 0 4}$ & $\mathbf{0 , 0 2}$ & $\mathbf{0 , 0 4}$ \\
\hline c8 & 0,08 & 0,34 & 0,58 & $\mathbf{3 , 0 4}$ & $\mathbf{0 , 0 2}$ & $\mathbf{0 , 0 3}$ \\
\hline c9 & 0,17 & 0,67 & 0,17 & $\mathbf{3 , 0 0}$ & $\mathbf{0 , 0 0}$ & $\mathbf{0 , 0 0}$ \\
\hline c10 & 0,24 & 0,14 & 0,62 & $\mathbf{3 , 0 3}$ & $\mathbf{0 , 0 1}$ & $\mathbf{0 , 0 2}$ \\
\hline c11 & 0,20 & 0,20 & 0,60 & $\mathbf{3 , 0 0}$ & $\mathbf{0 , 0 0}$ & $\mathbf{0 , 0 0}$ \\
\hline
\end{tabular}

Finally we obtain the overall priority (Table 8).

Table 8. Overall priority for AHP method

\begin{tabular}{|c|c|c|}
\hline No & Variant & \\
\hline A & Logasol SKN 4.0 & $\mathbf{0 , 3 2 8}$ \\
\hline B & Depsol DS 20 & $\mathbf{0 , 3 1 1}$ \\
\hline C & HEVELIUS SCM-20 58/1800 & $\mathbf{0 , 3 6 4}$ \\
\hline
\end{tabular}

In the PROMETHEE the intermediate results are presented in Tables 9 and 10 .

Table 9. Substitute criterion for partial criteria

\begin{tabular}{|c|c|c|c|c|c|c|}
\hline & 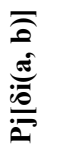 & 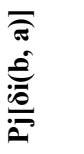 & 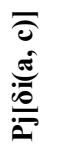 & 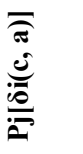 & 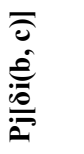 & $\begin{array}{l}\bar{a} \\
\stackrel{e}{0} \\
\stackrel{0}{0} \\
\stackrel{0}{0}\end{array}$ \\
\hline c1 & 1,00 & 0,00 & 0,00 & 1,00 & 0,00 & 1,00 \\
\hline c2 & 0,00 & 1,00 & 0,00 & 1,00 & 1,00 & 0,00 \\
\hline c3 & 1,00 & 0,00 & 1,00 & 0,00 & 1,00 & 0,00 \\
\hline c4 & 1,00 & 0,00 & 1,00 & 0,00 & 0,00 & 1,00 \\
\hline c5 & 0,00 & 0,00 & 0,45 & 0,00 & 0,52 & 0,00 \\
\hline c6 & 0,05 & 0,00 & 0,00 & 0,00 & 0,00 & 0,5 \\
\hline c7 & 0,00 & 1,00 & 0,00 & 1,00 & 0,00 & 1,00 \\
\hline c8 & 0,00 & 1,00 & 0,00 & 1,00 & 1,00 & 0,00 \\
\hline c9 & 0,00 & 1,00 & 0,00 & 0,00 & 1,00 & 0,00 \\
\hline c10 & 1,00 & 0,00 & 0,00 & 1,00 & 0,00 & 1,00 \\
\hline c11 & 0,00 & 0,00 & 0,00 & 0,50 & 0,00 & 0,50 \\
\hline
\end{tabular}

Subsequently for each pair of decision variants $\mathrm{x}$ and $\mathrm{y}$ is calculated aggregated indexes of preferences:

$$
\begin{aligned}
& \Pi(x, y)=\sum_{j=1}^{k} w_{j} P_{j}(x, y) \\
& \Pi(y, x)=\sum_{j=1}^{k} w_{j} P_{j}(y, x)
\end{aligned}
$$

Next, for each variant of the decision-making are calculated positive and negative flow preferences (1) and (2). 


$$
\begin{aligned}
& \Phi^{+}(x)=\frac{1}{n-1} \sum_{y \in A} \Pi(x, y) \\
& \Phi^{-}(x)=\frac{1}{n-1} \sum_{y \in A} \Pi(y, x)
\end{aligned}
$$

The final stage is to calculate net flows for each of the considered variants by using equations (3) and (4) (Table 10).

Table 10. Positive and negative flow preferences and net flows for each variants

\begin{tabular}{|c|c|c|c|}
\hline Variant & $\begin{array}{c}\text { Logasol } \\
\text { SKN 4.0 }\end{array}$ & $\begin{array}{c}\text { Depsol } \\
\text { DS 20 }\end{array}$ & $\begin{array}{c}\text { HEVELIUS } \\
\text { SCM-20 } \\
58 / 1800\end{array}$ \\
\hline Positive flow & 0,29996 & 0,3783 & 0,47174 \\
\hline Negative flow & 0,43371 & 0,4037 & 0,31255 \\
\hline NET FLOW & $\mathbf{- 0 , 1 3 3 7}$ & $\mathbf{- 0 , 0 2 5}$ & $\mathbf{0 , 1 5 9 2}$ \\
\hline
\end{tabular}

Taking into account the results of the encoding using the normalization method and Neuman - Morgenstern method, authors received Variant $\mathrm{B}$ as the best. Then the Variant $\mathrm{C}$ and Variant A. In a case of normalization, variants are scattered uniformly and in the case of Neuman - Morgenstern method Variant B advantage is significant and variants A and C have similar results (Fig. 2).

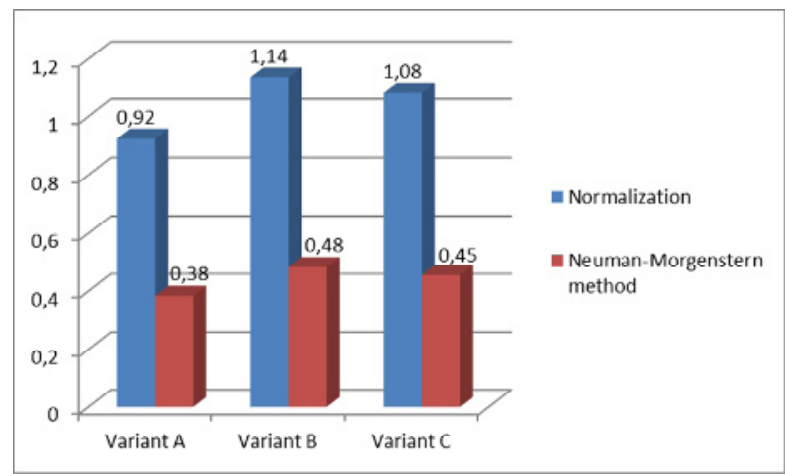

Figure 2. Assessment of variants for the normalization method and Neumann-Morgenstern method (Source: own).

In turn, the AHP method gives quite a different results. The best solution here is variant $C$, then variant $\mathrm{A}$, and the worst result gives a variant B (Fig. 3).

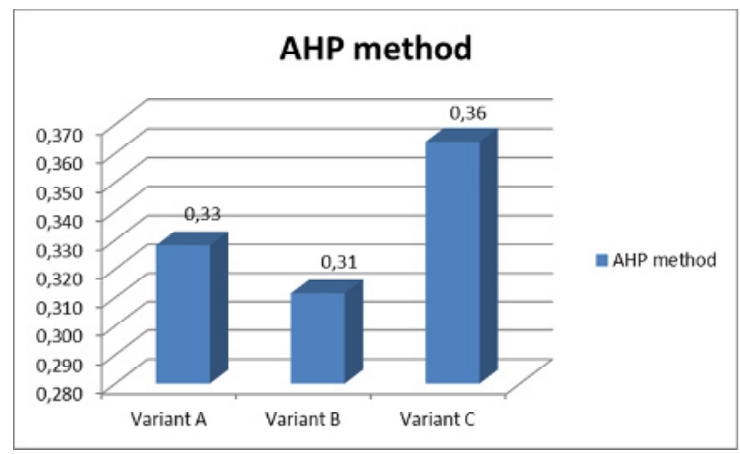

Figure 3. Assessment of variants by AHP (Source: own).

PROMETHEE II method generates results even different. Like the AHP method indicates the variant $\mathrm{C}$ as the best solution, but in second place situates variant B, and only as a last variant A (Fig. 4).

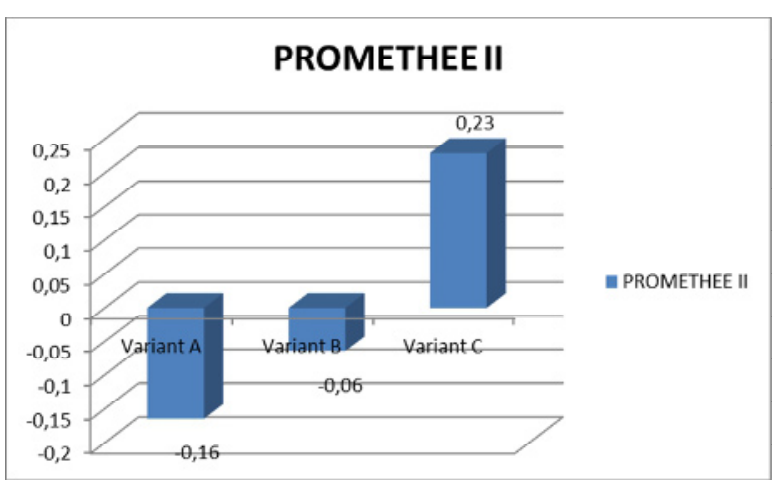

Figure 4. Assessment of variants by PROMETHEE II (Source: own).

\section{Conclusions}

Sustainability of buildings is currently investigated by a number of evaluation systems that reflect their design, technical, technological and material solutions [13]. In general, a measure of evaluation of alternative solutions is the level of performance criteria specified by the decision maker. The validity of the criteria, their selection, but also the choice of assessment methods substantially affect on the result of the analysis. Experts are expected to assessments consistent with the construction knowledge, reliable, objective and taking into account the specific of the decision situation. It is difficult to clearly define individual preferences, system of value and motives of an expert [14].

The advantage of taxonomic methods is the intuitiveness of use and the ability to give validity to each parameter, which reflects well the actual reality between the different criteria. As a disadvantage most often mentions the need for encryption of individual data, which often, depending on the choice of encoding method may influence the final result.

The advantages of AHP method are simplicity of making choices by comparison, and no need to use complicated mathematical calculations. Critical voices refer mainly to the lack of theoretical bases of the hierarchy construction, as a result, for exact decision situations it is possible to obtain different solutions. The second disadvantage which is most often mentioned is the high sensitivity to small changes and the impact on the final result even neutral criterion.

Application of PROMETHEE II allows for more realistic analysis of preferences, because this technique using the threshold of equivalence and the threshold preferences - take into account the fact that the real problems of decision-making accompain by an uncertainty, imprecision, indefiniteness and variability for both data as well as evaluations and preferences of participants in the decision making process. On the other hand, the subjective choice of preference function can significantly affect the final result.

The ranking procedure which represents the PROMETHEE II method takes into account 
uncertainty and imprecision of all the problems accompanying the decision that much more can reflect the reality of assumptions than the method consisting in calculating the weighted average. The best possible result in the PROMETHEE II method was repeated also in the calculation carried out by AHP which confirms the validity indication of Variant 3 as the most favorable.

\section{References}

1. K.Neupauer, J. Magiera, Efficiency analysis of different types of solar collectors, Tech. Trans., Issue 4, (2009)

2. B. J. Huang, V. A. Petrenko, I. YA. Samofatov and N. A. Shchetinina, Solar Energy 71(4), 269-274.

3. P. Aragonés-Beltrán, F. Chaparro-González, J.-P. Pastor-Ferrando, A. Pla-Rubio, Energy 66, 222-238 (2014)

4. J.R. San Cristóbal, Ren. En. 36, 498-502 (2011)

5. K. Zima, Case-Based Reasoning in Employer's Estimates", International Multidisciplinary Scientifif Geoconference, 14th GeoConference on Ecology, Economics, Education And Legislation Conference Proceedings, III, 17-26 June 2014, Bulgaria, 75-82.

6. Cinca M., Bancea O., \& Adam M. Study of energy saving in buildings for improved comfort conditions, 12th International Multidisciplinary Scientific GeoConference, SGEM 2012 Conference Proceedings, June 17-23, 2012, Vol. 5, 793-800;

7. Sedlakova A., Vojtus J., \& Burdova E. K. Design of consumer model and environmental assessment of used building materials, 12th International Multidisciplinary Scientific GeoConference, SGEM 2012 Conference Proceedings, June 17-23, 2012, 5, $235-242$.

8. A. Leśniak, Bid assessment with the use of fuzzy sets theory, Proceedings Of The International Conference Of Numerical Analysis And Applied Mathematics 2014 (ICNAAM-2014), AIP Conference Proceedings 1648, Article Number: UNSP 600006, 2015

9. A. Leśniak, E. Plebankiewicz, J. of Manag. in Eng. 31(2), 2013. Article Number: 04014032

10. K. Duzinkiewicz, Struktury i algorytmy wspomagania decyzji 2012/2013. Wieloatrybutowe problemy decyzyjne - metody rozwiązywania, Katedra Inżynierii Systemów Sterowania, Politechnika Gdańska [online][12.02.2016] http://slideplayer.pl/slide/59738/.

11. J. Szwabowski, J. Deszcz, Metody wielokryterialnej analizy porównawczej : podstawy teoretyczne i przykłady zastosowań w budownictwie, (Gliwice : Wydaw. Politechniki Śląskiej, 2001)

12. T. L. Saaty, Fundamentals of Decision Making and Priority Theory. (RWS Publications, Pittsburgh, Pennsylvania, 2001)

13. M. Kozlovska, R. Baskova, M. Krajnak, A. Tazikova, Sustainability of construction from perspective of applications technologies for green buildings, 4th International Multidisciplinary Scientific GeoConference SGEM Conference Proceedings, June 19-25, 2014, 6(2), 323-330 (2014)
14. M. Książek, Ekspercki system oceny rozwiązań w budownictwie, logitrans - VII Konferencja Naukowo-Techniczna Logistyka, Systemy Transportowe, Bezpieczeństwo w Transporcie, 11351145. 